\title{
Integrated Coastal Zone Management: A Public Policy. The Need for Communication, Coordination and Participation
}

\section{Garcia-Sanabria Javier}

Faculty of Marine and Environmental Sciences, University of Cadiz, Spain

*Corresponding author: García-Sanabria Javier, Faculty of Marine and Environmental Sciences, University of Cadiz, Spain, Tel: +0034-652794836; E-mail: javier.sanabria@uca.es

Received date: July 15, 2015, Accepted date: July 17, 2015, Published date: July 20, 2015

Copyright: $@ 2015$ Javier GS. This is an open-access article distributed under the terms of the Creative Commons Attribution License, which permits unrestricted use, distribution, and reproduction in any medium, provided the original author and source are credited.

\section{Introduction}

It is especially important precision in the use of language in the case of integrated management, as this aims to achieve shared objectives, consensus between different actors operating in the territory, with their different responsibilities, interests and conflicts. For this, communication is essential, especially when responsible managers or administrators usually act on behalf of public institutions.

Management (in the public domain) means a set of decisions, measures and activities that lead to resource management, the development of economic activities and the implementation of plans [1]. To manage is, therefore, the way of administrating goods and space, and brings order strategically allocating and using natural resources and economic activities, as well as the proper use of the mechanisms of implementation and monitoring of the decision [2]. Integrated coastal zone management (ICZM) can then be defined as a dynamic and ongoing process designed to promote sustainable development of coastal areas through the integration of policies, objectives, strategies and sectoral plans in space and time, and the integration of terrestrial and marine components of the coast [3].

On the contrary, sectoral management in the coast refer to that management system by which each of the uses and activities carried out on the coast are administered independently [4]. Examples of sectoral management are port management or tourism or environmental management. Integrated management has a transverse approach, and seeks to integrate all sectoral policies, objectives and instruments in space and time, also integrating terrestrial and marine components of the coast. Therefore it covers not only port, tourism and environmental sectors but those that develop in these areas, ranging from industrial to cultural activities, from fishing and agriculture to services and industry research, transport, urban development and trade, to name some.

Governance is another term that appears frequently when talking about ICZM and refers precisely to a more democratic and participatory management of these spaces. Governance is a model of government that aims at sustainable economic, social and institutional development, promoting a healthy balance between the state, civil society and market economy [3,5]. Consequently, the decision is not based, exclusively, on the principle of hierarchy but also in the participation, negotiation, consensus, cooperation, etc. Juda and Hennessey [6] defines governance as the formal and informal arrangements, institutions and mores that structure and influence: how resources or an environment are utilized; how problems, opportunities are evaluated or analysed; what behaviour is acceptable or forbidden; what rules and sanctions are applied to affect how natural resources are distributed and used.
Public participation in integrated management of coastal and marine areas should be interpreted as an on-going process that brings together the technical and policy makers with citizens in a particular initiative; especially if the latter are involved or interested in any way in these areas or in the coastal-marine ecosystems and their services [7]. It is clear therefore that the participation relates to the inclusion of all people, organizations and associations that do not perform official functions of government in the management process. Should be noted that participatory models are associated not only to the democratic country level, but also to its social and economic development [8].

Often participation has been resolved by public agencies by establishing open consultation period at the end of the drafting of a project, at which point it is difficult to make substantial changes to its content [7]. In these cases, it is normal that public participation is low, and that the original intention of convening public body is more similar to validate and legitimize the decisions taken in advance than to open a process of effective participation. It is a common paradox in many democratic countries to choose a representative democracy rather than a participatory democracy. According to Barragan [7], referring to this situation, "the formal participation should be considered a lower category, or even a degeneration, of the model of participation."

The coastal and marine issues must be addressed through transversal initiatives, ie, from a holistic and all-encompassing vision of the problems, according to their causes, and not just to their symptoms. Indeed, the management of coasts and seas are often related to different interests, sectors and activities taking place in the same space, resulting relationships and cumulative effects that should be treated together. For this, the intra and inter-agency collaboration is fundamental, understanding collaboration as that which is given between two or more actors or groups of actors working together so that the agendas and interests of each have equal importance. That is, the joint action between two or more parties to produce an outcome that could not be obtained through the isolated efforts of each one separately.

Once objectives have been defined for coastal management, it is necessary to consider not only both strategic and operational instruments for development, but also the resources to be allocated to implement them. Indeed, too often certain instruments have been limited in their application due to lack of adequate human and economic resources for its implementation $[9,10]$. "Resources" Resources mean not only the economic resources that are required, but also the people needed to implement the tools, including the training and updating of their knowledge, and the resources derived from the information needed when managing (information of the object of 
Page 2 of 2

management and the management itself), so that it can be taken a proactive, strategic and adaptive management.

In recent years, due to the initiative "Millennium Ecosystem Assessment" undertaken by the United Nations (UN) [11], it has been talking increasingly of ecosystem-based management. This term refers to a specific management of an area, with adaptive character, which takes into account the knowledge of the ecosystem and uncertainties, considers the multiple external influences and strives to balance social and environmental goals with particular emphasis on maintain ecosystems capacity to produce goods and services. It is a strategy for integrating the management of land, water and living resources and promotes conservation and sustainable use within a balanced and equitable way.

The ICZM is conceived as a public policy, understood this as a program of government action, resulted from a public intervention that is applied to a sector of society or a particular geographical area (Barragán, Chica and Perez-Cayeiro , 2008), which in our case will correspond to coastal-marine areas. Then, public policy means the set of ideas and values within which decisions regarding an issue or problem of interest are taken. Government policies guide decisions and actions that relate to society as a whole. In the case of ICZM it is associated with long-term time horizons. Public policies are developed by the federal-state scales, regional, provincial and municipal government. The importance of that policy goals for the management of marine coastal areas is crucial.

Once a particular issue has been incorporated into the political agenda, it can be developed through "reactive policies" when made in response to problems that appear, sometimes with certain danger, in the coastal and marine areas. Consider, for example an episode of oil spill. On the other hand, a problem can be subject to a "proactive policy", ie, when they are drafted to act before a given situation arises. This type of policy requires constant adaptation and should anticipate potential crises usually including strategic instruments (plans, strategies, etc) that must be flexible to adapt to real situations as they occur. ICZM occur in both types of policies, but in practice has been dominating the first, even though proactive policies are the most interesting in that they can avoid the problems by leading to changes in the management of coastal zones. Therefore, to move towards an Integrated Coastal Zone Management model, it is necessary to recognize two key issues:

ICZM is a particular public policy. This keystone should permeate those decision makers and public officials.
An ICZM policy must emphasize principles related to voluntariness, flexibility, coordination between institutions and territorial levels of management, cooperation between the public sector and nongovernmental, democratic legitimacy involving public participation, etc.

I really hope this special issue on ICZM helps in providing advice, experiences, innovative solutions and knowledge for continue advancing towards a more integrated coastal management.

\section{References:}

1. Barragán JM (2003) Medio ambiente y desarrollo en áreas litorales. Introducción a la Planificación y Gestión Integradas. Servicio de publicaciones Universidad de Cádiz, Cádiz: 301.

2. Pérez-Cayeiro ML (2013) Gestión Integrada de Áreas Litorales. Análisis de los fundamentos de la disciplina. Tébar, Madrid: 404.

3. Barragán JM, Chica JA, Pérez-Cayeiro ML (2008) Propuesta de Estrategia Andaluza de Gestión Integrada de Zonas Costeras. Consejería de Medio Ambiente de la Junta de Andalucía, Cádiz: 255.

4. Cicin- Sain B, Knech RW (1998) Integrated coastal and ocean management. Concepts and practice. Island Press, Washington, DC: 517.

5. Aguilar Villanueva Luis (2007) Gobernanza y gestión pública. Colección obras de Administración Pública, México: 500.

6. Lawrence Juda and Timothy Hennessey (2001) Governance Profiles and the Management of the Uses of Large Marine Ecosystems, Ocean Development and International Law 32: 43-69.

7. Barragán JM (2014) Política, gestión y litoral. Una nueva visión de la gestión integrada de áreas litorales. UNESCO y Editorial Tébar, Madrid: 620

8. Dalal-Clayton B, Swiderska K, Bass S (Editors) (2002) Stakeholder Dialogues on Sustainable Development Strategies. Lessons, Opportunities and Developing Country Case Studies. Environmental Planning Issues $n^{\circ}$ 26, International Institute for Environment and Development, London: 140.

9. Barragán JM (2010) Coastal management and public policy in Spain. Ocean \& Coastal Management 53: 209-217.

10. García-Sanabria J, García-Onetti J, Barragán JM (2011) Las Comunidades Autónomas y la gestión integrada de las áreas litorales en España. Materiales para un debate sobre gobernanza. Fundación Biodiversidad y Universidad de Cádiz: 220

11. UNEP (2006) Marine and coastal ecosystems and human well- being: A synthesis report based on the findings of the Millennium Ecosystem Assessment. UNEP: 76. 